\title{
Reaction of Certain Sugarcane Varieties to Infection with Pokkah Boeng Disease Caused by Fusarium Subglutenans.
}

Osman, M. A. M. ${ }^{1}$; M. A. E. Hassan ${ }^{2}$; M. M. A. El-Kholi ${ }^{1}$ and A.A. Abdel-Razik ${ }^{2}$

${ }^{1}$ Sugar Crop Research Institute, Dept. of Pests and Diseases of Sugar Crops, Agricultural Research Center, Giza, Egypt

${ }^{2}$ Dept. of Plant Pathology Faculty of Agriculture, Assiut Univ., 71526 Assiut, Egypt

\section{Abstract:}

Susceptibility of sixteen sugarcane varieties to infection with pokkah boeng disease and effect of the disease on vegetative growth of sugarcane plants were tested under open greenhouse conditions and artificial inoculation of Fusarium subglutinans in 2010/2011 and 2011/2012 seasons in Upper Egypt. All tested sugarcane varieties were susceptible to infection with the pathogen with different degrees of susceptibility. In the two tested seasons, the G.T.54-9 and G.2004-32 varieties showed high susceptibility followed by G.2003-47, G.2003-3, G.1999103 and G.1998-28, then other tested varieties. However, G.2001-79 and G.2000-176 varieties proved to be moderately susceptible. K2 isolate of $F$. subglutinans caused higher disease severity than $\mathrm{K} 5$ isolate, on the tested sugarcane varieties in both tested seasons. The interaction between tested varieties and fungal isolates was significant in both seasons. The highest disease severity ( $V$ Y.0 and 76.0\%) was recorded on G.T.54-9 and G.2004-32 varieties inoculated with K2 of $F$. subglutinans in both seasons, while the lowest disease severity (20.0\%) was recorded on G.2001-79 and G.2000-176 varieties infected with K2 and K5 isolates. Infection with of $F$. subglutinans isolates increased the number of tillers/plant by two folds in infected plants compared with non-inoculated plants in both seasons, however, the number of internodes/plant, stalk length and stalk diameter of the tested sugarcane varieties were significantly decreased by infection.

Keywords: Sugarcane plants, pokkah boeng disease, Fusarium subglutinans, sugarcane varieties, vegetative growth.

\begin{tabular}{l}
\hline \hline Received on: 15/4/2014 Accepted for publication on: 30/4/2014 \\
Referees: Prof. Mohamed A. Salam Prof. Mahamod R. Asran
\end{tabular}




\section{Introduction:}

Sugarcane is one of the most important crops for the sugar production in the world (Islam et al., 2001 and Vishwakarma et al., 2013). The sugarcane crop is affected by numerous diseases which caused great losses in yield of sugar and cane. In Egypt, sugarcane plants are attacked by several phytopathogenic fungi causing various root and stalk diseases (Martin et al., 1961). The pokkah boeng disease, caused by the fungus Fusarium moniliforme Sheldon, is becoming major disease of sugarcane. The occurrence of the disease has been recorded in almost all the cane growing countries in the world, i.e. Brazil, Cuba, Egypt, India and United States (Martin et al., 1961, Higgy et al., 1976 and Vishwakarma et al., 2013). Recent survey during 2007-13 showed increasing trend of disease incidence and most of the commercial cultivars affected by the disease ranged from 1-90\%. Although, pokkah boeng comes under minor concern but these days it is going to be major on basis of their rapid epidemiology during last few years (Vishwakarma et al., 2013).

Pokkah boeng is an air-borne disease and primarily transmitted through the air-currents and secondary transmission is through the infected setts, irrigation water, splashed rains and soil. The pathogen ( $F$. monilifome) can survive for 12 months in the plant debris under natural conditions. The severe incidence of the disease occurred in the range of temperature between $20-32^{\circ} \mathrm{C}$ and in rainy season. The control of plant diseases using classical fungicides raises serious concerns about food safety, environmental quality and fungicides resistance, which have dictated the need for alternative pathogens management techniques. In particular, resistance varieties could affect the disease tolerance or resistance of plants to pathogens and consider medium safety to control plant diseases. Planting of healthy seed material/use of resistant verities and follow of integrated disease management practices are the best way to prevent disease incidence (Lyrene et al., 1977 and Patil et al., 2007). F. moniliforme can be disseminated horizontally by airborne spores or crop debris and vertically through the seed pieces. So it is important to use of resistant varieties. This process for controlling is limited and there is increasing need for novel and environmentally sound strategies to control this and other diseases of sugarcane. The actual frequency and level of pokkah boeng resistance in Egyptian varieties in breeding and selection population are unknown. Thus, the objective of this work was to evaluate the introduced sugarcane varieties of to pokkah boeng disease under artificial conditions. Also, the effect of the disease on growth of sugarcane plants was assessed.

\section{Materials and Methods:}

\section{Sugarcane plants}

Reaction of sixteen sugarcane varieties (G.2000-5, G.2000-47, G.2003-47，G.2004-27，G.2003-3, G.2003-38，G.2003-44，G.1984-47, G.1999-103, G.2004-32, G.2001-79, G.1998-28, G.2000-176, G.2002-10, 
G.2003-1 and G.T.54-9) to infection with pokkah boeng disease was tested. The experiment was conducted at 2010/2011 and 2011/2012 growing seasons in the open greenhouse of El-Mattana Research Station, Luxor Governorate under artificial infection using $30 \mathrm{~cm}$ diameter pots filled with $5-\mathrm{kg}$ sterilized Nile silt soil. The soil and pots were sterilized with $5 \%$ formalin solution for 5 minutes. The soil was covered with a polyethylene sheet for seven days to retain the gas and left to dry for two weeks until all trace of formaldehyde disappeared. Surface sterilized singlebud cuttings of each sugarcane variety were planted. The cuttings were surface sterilized by soaking in $2 \%$ sodium hypochlorite solution for 5 minutes, washed thoroughly 3 times with sterilized distilled water. From each variety, 45 single-bud cuttings were divided to 3 replicates (5 cuttings/replicate). Five nods contain 5 buds were planted in each pot. Each single-bud cuttings was trimmed to leave $1-2 \mathrm{~cm}$ of internode tissue on each side and three pots were used per isolate and five nods contain 5 buds were planted in each pot on the first week of march. The pots were watered after planting, fertilizer of sugarcane was applied routinely as mentioned in recommendation of Egyptian Ministry of Agriculture and kept in open greenhouse.

\section{Fungal pathogen isolates and in- oculum preparation}

The two highly pathogenic isolates $\mathrm{K} 2$ and $\mathrm{K} 5$ of Fusarium subglutinans (Wollenweber \& Reinking) Nelson et al. were obtained from the culture collection of plant pathology Department, Faculty of Agriculture, Assiut University, Assiut, Egypt. Inocula of isolates were prepared on PDA medium at $30^{\circ} \mathrm{C}$ for ten days. Spore suspension of each isolate was prepared by flooding each of fungal plants with $10 \mathrm{ml}$ sterilized water for 1-2 minutes to release the spores. The concentration of spore suspension was adjusted to reach $10^{6} \mathrm{CFU} / \mathrm{ml}$ (Yates et al. 1997) using a haemocytometer slide.

\section{Inoculation and evaluation of disease}

Sugarcane seedlings (45 days old) were inoculated with each fungal isolates. For inoculation, leaf spindles of each plant were fully sprayed with spore suspension of each isolate using an Atomizer as described by Priode (1929). The control plants were sprayed with distilled water. The inoculated and non-inoculated plants were covered with clear polyethylene pages over night. Three pots contained five seedling were used for each isolate as well as the control treatment. After six months from inoculation, the disease severity percentage (DS\%) of pokkah boeng was evaluated using a rating system from $0-5$ according to the modified scale designed by (Ramirez and Nass, 2005) as follow: $0=$ Healthy phase (No symptoms); $1=$ Chlorotic phase (Leaves showing chlorosis, narrowing and distortion); 2 = Leaf crinkling and twiste phase (Spindel showing leaf crinkling and not completely folding); $3=$ Top-Rot phase (Stalk showing top rot and apical bud and side shoot 
development); 4 = Ladder-like lesions phase (Stalk showing ladderlike lesions); $5=$ Knife-cut phase (Stalk showing terminal knife cut and side shoot development).

Disease severity (DS\%) index was calculated by the following equation:

$\mathrm{DS} \%=\frac{\Sigma(\mathrm{Ax} \mathrm{n})}{\Sigma \mathrm{B} \times \text { Maximum possible score (5) }} \times 100$

$\mathbf{A}=$ disease scale $(0,1,2,3,4$ or 5$)$.

$\mathbf{n}=$ number of stalks for each disease scale.

$\mathbf{B}=$ total number of stalks. mez and Gomez., 1984). Using means of "MSTAT-C" computer software program package according to (Freed et al., 1989).

Results:

1. Susceptibility of certain sugarcane varieties to the disease:

Reaction of sixteen sugarcane varieties (G.2000-5, G.2000-47, G.2003-47, G.2004-27, G.2003-3, G.2003-38，G.2003-44，G.1984-47, G.1999-103，G.2004-32，G.2001-79, G.1998-28, G.2000-176, G.2002-10, G.2003-1 and G.T.54-9) to infection with the disease was tested under open greenhouse conditions and artificial inoculation with $\mathrm{K} 2$ and $\mathrm{K} 5$ isolates of Fusarium subglutinans in 2010/2011 and 2011/2012 successive seasons.

Data presented in Table (1) indicate that the tested sixteen sugarcane varieties were susceptible to infection with both isolates of the pathogen with different degrees of susceptibility. In the two tested seasons, the G.T.54-9 and G.2004-32 varieties show high susceptibility to both $\mathrm{K} 2$ and $\mathrm{K} 5$ isolates followed by G.2003-47, G.2003-3， G.1999-103 and G.1998-28 then other tested varieties. However, G.2001-79 and G.2000-176 varieties proved to be moderately susceptible to pokkah boeng disease. 
Table (1): Susceptibility of certain sugarcane varieties to infection with K2 and K5 isolates of Fusarium subglutinans in 2010/2011 and 2011/2012 growing seasons, under greenhouse conditions.

\begin{tabular}{|c|c|c|c|c|c|c|}
\hline \multirow[b]{3}{*}{ Variety } & \multicolumn{6}{|c|}{ Disease severity percentage } \\
\hline & \multicolumn{3}{|c|}{ 2010/2011 Season } & \multicolumn{3}{|c|}{ 2011/2012 Season } \\
\hline & K2 Isolate & K5 Isolate & Mean & K2 Isolate & K5 Isolate & Mean \\
\hline G.2000-5 & 40.00 & Tr, & 36.00 & 44.00 & 40.00 & 42.00 \\
\hline G.2000-47 & $r \cdot, \cdots$ & Tr,., & 26.00 & 28.00 & 36.00 & 32.00 \\
\hline G.2003-47 & $7 \varepsilon, \cdots$ & $\varepsilon \wedge, \cdots$ & 56.00 & 60.00 & 40.00 & 50.00 \\
\hline G.2004-27 & $r \leqslant, \cdots$ & $r \cdot, \cdots$ & 22.00 & 29.00 & 32.00 & 30.50 \\
\hline G.2003-3 & rq, . & $07, \cdots$ & 46.00 & 40.00 & 48.00 & 44.00 \\
\hline G.2003-38 & Tr,. & $\varepsilon \cdot, \cdots$ & 36.00 & 32.00 & 40.00 & 36.00 \\
\hline G.2003-44 & $07, \cdots$ & $r \cdot, \cdots$ & 38.00 & 52.00 & 24.00 & 38.00 \\
\hline G.1984-47 & $\varepsilon \cdot, \cdots$ & $r \cdot, \cdots$ & 30.00 & 44.00 & 28.00 & 36.00 \\
\hline G.1999-103 & $07, \cdots$ & $\varepsilon \cdot, \cdots$ & 48.00 & 56.00 & 44.00 & 50.00 \\
\hline G.2004-32 & $V Y, \cdots$ & $07, \cdots$ & 64.00 & 68.00 & 52.00 & 60.00 \\
\hline G.2001-79 & $r \cdot, \cdots$ & $r \cdot, \cdots$ & 20.00 & 24.00 & 32.00 & 28.00 \\
\hline G.1998-28 & $7 \varepsilon, \cdots$ & $r \leqslant, \cdots$ & 44.00 & 60.00 & 24.00 & 42.00 \\
\hline G.2000-176 & $r \cdot, \cdots$ & $r \cdot, \cdots$ & 20.00 & 28.00 & 20.00 & 24.00 \\
\hline G.2002-10 & Tr,.. & $\varepsilon \cdot, \cdots$ & 36.00 & 36.00 & 32.00 & 34.00 \\
\hline G.2003-1 & $\varepsilon \cdot, \cdots$ & $r \cdot, \cdot \cdot$ & 30.00 & 40.00 & $r \wedge, \cdots$ & 34.00 \\
\hline G.T. 54-9 & $V Y, \cdots$ & $7 \varepsilon, \cdots$ & 68.00 & 76.00 & 72.00 & 74.00 \\
\hline Mean & 43.01 & 34.50 & 38.75 & 44.81 & 37.00 & 40.91 \\
\hline \multicolumn{7}{|l|}{ LSD at $5 \%$} \\
\hline Variety & & & 5.98 & & & 4.95 \\
\hline Isolate & & & 1.74 & & & 1.58 \\
\hline Interaction & & & 6.97 & & & 6.33 \\
\hline
\end{tabular}

Data also indicated that $\mathrm{K} 2$ isolate caused higher disease severity than K5 isolate, on the tested sugarcane varieties in both seasons.

Results also showed that the interaction between tested varieties and fungal isolates was significant in both seasons. The highest disease severity ( $\vee$ Y.0 and $76.0 \%$ ) was recorded on G.T.54-9 and G.2004-32 varieties inoculated with $\mathrm{K} 2$ of $F$. subglutinans in both seasons, while the lowest disease severity $(20.0 \%)$ was recorded on G.2001-79 and G.2000-176 varieties infected with $\mathrm{K} 2$ and $\mathrm{K} 5$ isolate of $F$. subglutinans.

\section{Effect of infection with pokkah boeng disease on number of tillers/plant:}

Data in Table (2) indicate that pokkah boeng disease increased significantly number of tillers/plant of the tested sugarcane varieties in the two test seasons. The highest number of tillers/plant (19.33 and 15.67 tillers/plant) was obtained by G.2003-38 variety in the first and second sea- sons, respectively. However, the lowest number of tillers/plant (1.0 and 3.0 tillers/plant) was recorded in G.2004-27 variety in both seasons.

In general, concerning the effect of infection with fungal pathogen isolates on number of tillers/plant under pathogen stress it was observed that the number of tillers/plant was increased by two folds in infected plants with $\mathrm{K} 2$ or $\mathrm{K} 5$ isolates of $F$. subglutinans in both seasons compared with non- inoculated sugarcane plants (4.44 and 5.50 tillers/plant).

The highest number of tillers (20.0 and 26.0 tillers/plant) and (15.0 and 22.0 tillers/plant) was recorded in G.2003-38 variety infected with K2 and $\mathrm{K} 5$ isolates of $F$. subglutinans in the first and second seasons, respectively. On the other hand, in the first and second seasons the lowest number of tillers (1.0 and 2.0 tillers/plant) was recorded in G.2004-27 variety after infection with $\mathrm{K} 2$ and $\mathrm{K} 5$ isolates, respectively. 
Table (2): Effect of pokkah boeng disease caused by $F$. subglutinans isolates $K 2$ and $K 5$ on number of tillers/plant of certain sugarcane varieties in 2010/2011 and 2011/2012 growing seasons, under greenhouse conditions.

\begin{tabular}{|c|c|c|c|c|c|c|c|c|}
\hline \multirow[b]{3}{*}{ Variety } & \multicolumn{8}{|c|}{ Number of tillers/plant } \\
\hline & \multicolumn{4}{|c|}{ 2010/2011 Season } & \multicolumn{4}{|c|}{ 2011/2012 Season } \\
\hline & $\begin{array}{c}\text { Non- } \\
\text { inoculated }\end{array}$ & $\begin{array}{c}\text { K2 } \\
\text { Isolate }\end{array}$ & $\begin{array}{c}\text { K5 } \\
\text { Isolate }\end{array}$ & Mean & $\begin{array}{c}\text { Non- } \\
\text { inoculated }\end{array}$ & $\begin{array}{c}\text { K2 } \\
\text { Isolate }\end{array}$ & $\begin{array}{c}\text { K5 } \\
\text { Isolate }\end{array}$ & Mean \\
\hline G.2000-5 & $7, \cdots$ & $17, \cdots$ & $1 \cdot, \ldots$ & 10.67 & 5.00 & 14.00 & 8.00 & 9.00 \\
\hline G.2000-47 & $r, \ldots$ & $7, \cdots$ & $7, \cdots$ & 4.67 & 2.00 & 8.00 & 5.00 & 5.00 \\
\hline G.2003-47 & $\varepsilon, \ldots$ & $10, \ldots$ & $\Lambda, \cdots$ & 9.00 & 4.00 & 10.00 & 6.00 & 6.67 \\
\hline G.2004-27 & $1, \cdots$ & $1, \cdots$ & $1, \cdots$ & $1, \cdots$ & 2.00 & 5.00 & 2.00 & 3.00 \\
\hline G.2003-3 & $0, \cdots$ & $1 \wedge, \cdots$ & $11, \cdots$ & 11.33 & 7.00 & 14.00 & 12.00 & 11.00 \\
\hline G.2003-38 & IY, . & $r \cdot, \cdots$ & rq, & 19.33 & 10.00 & 15.00 & 22.00 & 15.67 \\
\hline G.2003-44 & $\varepsilon, \ldots$ & $1 \cdot, \cdots$ & $\varepsilon, \cdots$ & 6.00 & 4.00 & 11.00 & 5.00 & 6.67 \\
\hline G.1984-47 & $r, \ldots$ & $v, \ldots$ & $\varepsilon, \cdots$ & 4.33 & 4.00 & 5.00 & 6.00 & 5.00 \\
\hline G.1999-103 & $r, \ldots$ & $9, \ldots$ & $1 \varepsilon, \cdots$ & 8.67 & 5.00 & 10.00 & 11.00 & 8.67 \\
\hline G.2004-32 & $9, \ldots$ & IY, . & $1 \leq, \cdots$ & 11.67 & 10.00 & 12.00 & 14.00 & 12.00 \\
\hline G.2001-79 & $r, \ldots$ & $\mathrm{v}, \ldots$ & $0, \ldots$ & 4.67 & 3.00 & 6.00 & 5.00 & 4.67 \\
\hline G.1998-28 & $v, \ldots$ & IY, . & $1 \pi, \ldots$ & 10.67 & 9.00 & 15.00 & 12.00 & 12.00 \\
\hline G.2000-176 & $1, \cdots$ & $0, \cdots$ & $7, \cdots$ & 4.00 & 4.00 & 7.00 & 5.00 & 5.33 \\
\hline G.2002-10 & $r, \ldots$ & $\wedge, \cdot \cdot$ & $1, \ldots$ & 7.00 & 6.00 & 10.00 & 9.00 & 8.33 \\
\hline G.2003-1 & $\Lambda, \cdots$ & IY, . & $1 Y, \ldots$ & 10.67 & $v, \ldots$ & 9.00 & 10.00 & 8.67 \\
\hline G.T. 54-9 & $r, \ldots$ & $11, \cdots$ & $1,, \ldots$ & 8.00 & 5.00 & $\Lambda, \cdots$ & 8.00 & 7.00 \\
\hline Mean & 4.50 & 10.56 & 9.63 & 8.23 & 5.44 & 9.94 & 8.75 & 8.04 \\
\hline \multicolumn{9}{|l|}{ LSD at $5 \%$} \\
\hline Variety & & & & 0.83 & & & & 0.91 \\
\hline Isolate & & & & 0.36 & & & & 0.39 \\
\hline Interaction & & & & 1.44 & & & & 1.57 \\
\hline
\end{tabular}

\section{Effect of infection with pokkah boeng disease on number of internodes/plant}

Table (3) show that the highest number of internodes/plant (21.13 and 21.27 internodes/plant) was found in G.2003-1 variety in the first and second seasons, respectively. Moreover, the lowest number of internodes/plant (16.13 and 16.80 internodes/plant) and (17.83 and 17.58 internodes/plant) was found in G.2003-38 and G. 2000-5 varieties in the first and second seasons, respectively.

Although, the number of internodes/plant of sugarcane plants markedly decreased after infection with $\mathrm{K} 2$ or K5 isolates of $F$. subglutinans, insignificant differences be- tween both isolates in their effect were observed in both seasons.

Compared with non-inoculated control plants in first and second seasons, the infection with both $\mathrm{K} 2$ and $\mathrm{K} 5$ isolates of the fungal pathogen significantly decreased the number of internodes/plant in each sugarcane variety. G.2003-1 sugarcane variety showed the highest number of internodes/plant (20.40, 20.80, 21.30 and 21.25 internodes/plant) in the first and second seasons under infection by $\mathrm{K} 2$ and $\mathrm{K} 5$ isolates, respectively. On the other hand, G.2003-38 variety infected with $\mathrm{K} 2$ isolate show the lowest number of internodes/plant (13.40 and 15.25 internodes/plant) in both seasons. 
Table (3): Effect of pokkah boeng disease caused by $F$. subglutinans isolates $\mathrm{K} 2$ and $\mathrm{K5}$ on number of internodes/plant of certain sugarcane varieties in 2010/2011 and 2011/2012 growing seasons, under greenhouse conditions.

\begin{tabular}{|c|c|c|c|c|c|c|c|c|}
\hline \multirow[b]{3}{*}{ Variety } & \multicolumn{8}{|c|}{ Number of internodes/plant } \\
\hline & \multicolumn{4}{|c|}{ 2010/2011 Season } & \multicolumn{4}{|c|}{ 2011/2012 Season } \\
\hline & $\begin{array}{c}\text { Non- } \\
\text { inoculated }\end{array}$ & $\begin{array}{c}\text { K2 } \\
\text { Isolate }\end{array}$ & $\begin{array}{c}\text { K5 } \\
\text { Isolate }\end{array}$ & Mean & $\begin{array}{c}\text { Non- } \\
\text { inoculated }\end{array}$ & $\begin{array}{c}\text { K2 } \\
\text { Isolate }\end{array}$ & $\begin{array}{c}\text { K5 } \\
\text { Isolate }\end{array}$ & Mean \\
\hline G.2000-5 & 18.00 & 16.00 & 16.40 & 16.80 & 20.00 & 16.50 & 16.25 & 17.58 \\
\hline G.2000-47 & 19.60 & 17.00 & 16.00 & 17.53 & 19.00 & 18.50 & 18.25 & 18.58 \\
\hline G.2003-47 & 20.60 & 17.40 & 17.40 & 18.47 & 18.30 & 18.00 & 18.00 & 18.10 \\
\hline G.2004-27 & 20.00 & 18.00 & 19.60 & 19.20 & 20.50 & 18.75 & 19.60 & 19.62 \\
\hline G.2003-3 & 19.00 & 17.60 & 18.80 & 18.47 & 21.00 & 18.00 & 19.00 & 19.33 \\
\hline G.2003-38 & 18.00 & 13.40 & 17.00 & 16.13 & 20.00 & 15.25 & 18.25 & 17.83 \\
\hline G.2003-44 & 22.00 & 18.20 & 16.60 & 18.93 & 20.30 & 18.75 & 17.00 & 18.68 \\
\hline G.1984-47 & 19.20 & 18.00 & 16.80 & 18.00 & 21.13 & 18.50 & 17.50 & 19.04 \\
\hline G.1999-103 & 20.00 & 18.00 & 19.00 & 19.00 & 20.00 & 18.75 & 20.00 & 19.58 \\
\hline G.2004-32 & 21.00 & 17.80 & 17.20 & 18.67 & 22.15 & 19.25 & 17.75 & 19.72 \\
\hline G.2001-79 & 20.60 & 18.80 & 18.40 & 19.27 & 20.56 & 19.75 & 19.00 & 19.77 \\
\hline G.1998-28 & 19.40 & 17.80 & 16.40 & 17.87 & 21.13 & 18.00 & 17.00 & 18.71 \\
\hline G.2000-176 & 19.20 & 18.00 & 17.20 & 18.13 & 20.50 & 19.25 & 17.50 & 19.08 \\
\hline G.2002-10 & 22.60 & 19.00 & 17.20 & 19.60 & 21.14 & 20.00 & 18.00 & 19.71 \\
\hline G.2003-1 & 22.20 & 20.40 & 20.80 & 21.13 & 21.30 & 21.25 & 21.25 & 21.27 \\
\hline G.T. 54-9 & 21.20 & 20.00 & 20.40 & 20.53 & 22.16 & 20.75 & 20.75 & 21.22 \\
\hline Mean & 20.16 & 17.84 & 17.83 & 18.61 & 20.57 & 18.70 & 18.44 & 19.24 \\
\hline \multicolumn{9}{|l|}{ LSD at $5 \%$} \\
\hline Variety & & & & 0.79 & & & & 0.72 \\
\hline Isolate & & & & 0.34 & & & & 0.31 \\
\hline Interaction & & & & 1.37 & & & & 1.25 \\
\hline
\end{tabular}

\section{Effect of infection with pokkah boeng disease on stalk length (cm)}

Data presented in Table (4) show that the stalk length of sugarcane plants significantly reduced by infection with fungal pathogen in the most of tested sugarcane varieties. The greatest reduction of stalk length of sugarcane plants was recorded in G.2003-3 variety (112.67 and 111.0 $\mathrm{cm}$ ) in the first and second seasons, respectively, while the least reduction of stalk length $(151.33$ and $150.0 \mathrm{~cm})$ was recorded in G.2000-176 variety in first and second seasons, respectively.

Although, the stalk length of sugarcane plants was higher in noninoculated plants (147.13 and 148.00 $\mathrm{cm})$ than in plants infected with $\mathrm{K} 2$ and $\mathrm{K} 5$ isolates of $F$. subglutinans $(130.13,130.44$ and 129.13 and
$128.06 \mathrm{~cm})$ in the first and second seasons, respectively. No significant differences were observed in the effect of the tested isolates on stalk length, in both seasons.

Results also indicate that highest stalk length in infected plants $(152.0$ and $148.0 \mathrm{~cm})$ was recorded in G.2000-176 variety infected with K2 isolate of $F$. subglutinans in first and second seasons, respectively. Lowest stalk length was recorded in G.200338 variety in both seasons, Whereas, in the first season stalk length decreased from $152.0 \mathrm{~cm}$ to $88.0 \mathrm{~cm}$ in plants infected with $\mathrm{K} 2$ isolate and from $150.0 \mathrm{~cm}$ to $105.0 \mathrm{~cm}$ in the second season. In the same sugarcane variety, the isolate $\mathrm{K} 5$ of $F$. subglutinans exhibited the lowest decrease in stalk length $(108.0$ and $106.0 \mathrm{~cm})$ in first and second season, respectively. 
Table (4): Effect of pokkah boeng disease caused by $F$. subglutinans isolates $\mathrm{K} 2$ and $\mathrm{K5}$ on stalk length $(\mathrm{cm})$ of certain sugarcane varieties in 2010/2011 and 2011/2012 growing seasons, under greenhouse conditions.

\begin{tabular}{|c|c|c|c|c|c|c|c|c|}
\hline \multirow{3}{*}{ Variety } & \multicolumn{8}{|c|}{ Stalk length $(\mathrm{cm})$} \\
\hline & \multicolumn{4}{|c|}{ 2010/2011 Season } & \multicolumn{4}{|c|}{ 2011/2012 Season } \\
\hline & $\begin{array}{c}\text { Non- } \\
\text { inoculated }\end{array}$ & $\begin{array}{c}\text { K2 } \\
\text { Isolate }\end{array}$ & $\begin{array}{c}\text { K5 } \\
\text { Isolate }\end{array}$ & Mean & $\begin{array}{c}\text { Non- } \\
\text { inoculated }\end{array}$ & $\begin{array}{c}\text { K2 } \\
\text { Isolate }\end{array}$ & \begin{tabular}{|c|} 
K5 \\
Isolate
\end{tabular} & Mean \\
\hline G.2000-5 & 130.00 & 114.00 & 120.00 & 121.33 & 140.00 & 108.00 & 117.00 & 121.67 \\
\hline G.2000-47 & 155.00 & 126.00 & 110.00 & 130.33 & 150.00 & 125.00 & 108.00 & 127.67 \\
\hline G.2003-47 & 132.00 & 104.00 & 122.00 & 119.33 & 135.00 & 107.00 & 127.00 & 123.00 \\
\hline G.2004-27 & 134.00 & 128.00 & 119.00 & 127.00 & 135.00 & 130.00 & 122.00 & 129.00 \\
\hline G.2003-3 & 116.00 & 110.00 & 112.00 & 112.67 & 117.00 & 106.00 & 110.00 & 111.00 \\
\hline G.2003-38 & 152.00 & 88.00 & 108.00 & 116.00 & 150.00 & 105.00 & 106.00 & 120.33 \\
\hline G.2003-44 & 146.00 & 138.00 & 126.00 & 136.67 & 152.00 & 140.00 & 131.00 & 141.00 \\
\hline G.1984-47 & 152.00 & 142.00 & 130.00 & 141.33 & 150.00 & 136.00 & 128.00 & 138.00 \\
\hline G.1999-103 & 152.00 & 144.00 & 142.00 & 146.00 & 147.00 & 140.00 & 135.00 & 140.67 \\
\hline G.2004-32 & 149.00 & 142.00 & 138.00 & 143.00 & 155.00 & 145.00 & 130.00 & 143.33 \\
\hline G.2001-79 & 153.00 & 148.00 & 122.00 & 141.00 & 158.00 & 143.00 & 122.00 & 141.00 \\
\hline G.1998-28 & 157.00 & 140.00 & 142.00 & 146.33 & 155.00 & 145.00 & 136.00 & 145.33 \\
\hline G.2000-176 & 156.00 & 152.00 & 146.00 & 151.33 & 157.00 & 148.00 & 145.00 & 150.00 \\
\hline G.2002-10 & 150.00 & 138.00 & 142.00 & 143.33 & 150.00 & 140.00 & 143.00 & 144.33 \\
\hline G.2003-1 & 152.00 & 136.00 & 144.00 & 144.00 & 153.00 & 132.00 & 142.00 & 142.33 \\
\hline G.T. 54-9 & 168.00 & 132.00 & 143.00 & 147.67 & 164.00 & 137.00 & 147.00 & 149.33 \\
\hline Mean & 147.13 & 130.13 & 129.13 & 135.46 & 148.00 & 130.44 & 128.06 & 135.50 \\
\hline \multicolumn{9}{|l|}{ LSD at $5 \%$} \\
\hline Variety & $\mathbf{A}$ & & & 7.64 & & & & 5.60 \\
\hline Isolate & B & & & 3.31 & & & & 2.42 \\
\hline Interaction & $\mathbf{A x B}$ & & & 13.23 & & & & 9.70 \\
\hline
\end{tabular}

5. Effect of infection with pokkah boeng disease on stalk diameter (cm)

Data in Table (5) demonstrate clearly that the infection of sugarcane plants with both tested isolates (K2 and $\mathrm{K} 5$ ) resulted a decrease in stalk cane diameter in tested sugarcane varieties, in the two growing seasons. The greatest decrease in stalk diameter was recorded in G.1984-47 variety $(1.53 \mathrm{~cm})$ in the first season, and $(1.6$ $\mathrm{cm})$ in G.2000-5 variety in the second season. On the other hand, the least decrease in stalk diameter $1.91 \mathrm{~cm}$ was observed in G.2000-47 variety in the first season and was $2.07 \mathrm{~cm}$ in G.2003-44 variety in the second season.

Under artificial infection with $\mathrm{K} 2$ or K5 isolates of F. subglutinans, the stalk diameter of sugarcane markedly decreased by 20.21 and $13.50 \%$ in the first season, and by 24.3 and $18.10 \%$ in the second season. The stalk diameter of cane was lower in plants infected with K2 (1.54 and $1.59 \mathrm{~cm})$ than in plants infected with $\mathrm{K} 5(1.67$ and $1.72 \mathrm{~cm})$ in first and second seasons, respectively.

Data also show that the highest stalk diameter in infected plants (1.86 and $1.96 \mathrm{~cm}$ ) was recorded in G.2003-44 variety infected with K5 isolate of $F$. subglutinans in the first and second seasons, respectively. While, the lowest stalk diameter (1.32 and $1.40 \mathrm{~cm}$ ) was recorded in G.2003-44 and G. 2000-5 varieties infected with K2 isolate of the pathogen in the first and second seasons, respectively. 
Table (5): Effect of pokkah boeng disease caused by $F$. subglutinans isolates $\mathrm{K} 2$ and $\mathrm{K5}$ on stalk diameter $(\mathrm{cm})$ of certain sugarcane varieties in 2010/2011 and 2011/2012 growing seasons, under greenhouse conditions.

\begin{tabular}{|c|c|c|c|c|c|c|c|c|}
\hline \multirow[b]{3}{*}{ Variety } & \multicolumn{8}{|c|}{ Stalk diameter $(\mathrm{cm})$. } \\
\hline & \multicolumn{4}{|c|}{ 2010/2011 Season } & \multicolumn{4}{|c|}{ 2011/2012 Season } \\
\hline & $\begin{array}{c}\text { Non- } \\
\text { inoculated }\end{array}$ & $\begin{array}{c}\text { K2 } \\
\text { Isolate }\end{array}$ & $\begin{array}{r}\text { K5 } \\
\text { Isolate }\end{array}$ & Mean & $\begin{array}{c}\text { Non- } \\
\text { inoculated }\end{array}$ & $\begin{array}{r}\text { K2 } \\
\text { Isolate }\end{array}$ & $\begin{array}{r}\text { K5 } \\
\text { Isolate }\end{array}$ & Mean \\
\hline G.2000-5 & 1.78 & 1.60 & 1.68 & 1.69 & 1.80 & 1.40 & 1.60 & 1.60 \\
\hline G.2000-47 & 2.18 & 1.72 & 1.82 & 1.91 & 2.00 & 1.60 & 1.64 & 1.75 \\
\hline G.2003-47 & 1.72 & 1.50 & 1.56 & 1.59 & 1.90 & 1.70 & 1.60 & 1.73 \\
\hline G.2004-27 & 1.94 & 1.56 & 1.68 & 1.73 & 2.10 & 1.50 & 1.66 & 1.75 \\
\hline G.2003-3 & 1.72 & 1.60 & 1.56 & 1.63 & 1.92 & 1.50 & 1.78 & 1.73 \\
\hline G.2003-38 & 2.06 & 1.44 & 1.66 & 1.72 & 2.30 & 1.50 & 1.66 & 1.82 \\
\hline G.2003-44 & 2.26 & 1.32 & 1.86 & 1.81 & 2.50 & 1.74 & 1.96 & 2.07 \\
\hline G.1984-47 & 1.68 & 1.36 & 1.56 & 1.53 & 1.92 & 1.50 & 1.64 & 1.69 \\
\hline G.1999-103 & 2.02 & 1.48 & 1.62 & 1.71 & 2.40 & 1.68 & 1.66 & 1.91 \\
\hline G.2004-32 & 1.84 & 1.50 & 1.80 & 1.71 & 1.90 & 1.56 & 1.88 & 1.78 \\
\hline G.2001-79 & 1.86 & 1.66 & 1.72 & 1.75 & 1.90 & 1.58 & 1.78 & 1.75 \\
\hline G.1998-28 & 2.02 & 1.52 & 1.72 & 1.75 & 2.30 & 1.60 & 1.90 & 1.93 \\
\hline G.2000-176 & 2.08 & 1.70 & 1.58 & 1.79 & 2.00 & 1.68 & 1.62 & 1.77 \\
\hline G.2002-10 & 1.80 & 1.46 & 1.56 & 1.61 & 2.40 & 1.54 & 1.58 & 1.84 \\
\hline G.2003-1 & 1.74 & 1.62 & 1.58 & 1.65 & 1.92 & 1.46 & 1.68 & 1.69 \\
\hline G.T. 54-9 & 2.16 & 1.62 & 1.80 & 1.86 & 2.30 & 1.88 & 1.84 & 2.01 \\
\hline Mean & 1.93 & 1.54 & 1.67 & 1.72 & 2.10 & 1.59 & 1.72 & 1.80 \\
\hline \multicolumn{9}{|l|}{ LSD at $5 \%$} \\
\hline Variety & & & & $\cdot, 1 r$ & & & & 0.12 \\
\hline Isolate & & & & 0.05 & & & & 0.05 \\
\hline Interaction & & & & 0.21 & & & & 0.20 \\
\hline
\end{tabular}

\section{Discussion:}

Evaluation of sixteen sugarcane varieties to pokkah boeng disease caused by $F$. subglutinans fungs, under greenhouse conditions during 2010/2011 and 2011/2012 seasons was carried out. All tested sugarcane varieties were susceptible to infection with the tested isolates of the pathogen (K2 and K5) with different degrees of susceptibility. Degree of infection on the tested hosts and the virulence of the isolates varied from weak to severe. Variation in susceptibility among sugarcane varieties was reported by Priod (1929), Ahmad and Ali (1991), Chattha et al., (1999), Javed et al., (2001), Chattha et al., (2002), Solanky et al., (2003), Urdaneta and Borges (2008), Rahman et al., (2009) and Cuenya et al., (2011).

For a resistant variety, the pathogen that was inoculated may have penetrated the plant tissues but there was no occurrence of disease symptoms due to unsuitable hostpathogen relationships. The resistant plants may respond to penetration by producing self-defense mechanisms such as biochemical and physiological defense mechanisms that killed the pathogen or prevent its spread through the plant (Dickinson and Lucas, 1982; Agrios, 2005). This may explaine why some isolates caused chlorotic symptoms at early stages and after that the inoculated plants recovered. At the beginning, the symptoms caused by pathogen were chlorotic with some isolates twisted leaves but the symptoms slowly disappear and the plants recovered. This phenomenon usually happens to sugarcane with pokkah boeng disease if infection is limited to the leaves and new leaves will then develop normally (Blackburn, 1984). For susceptible variety, it appeared that there was a relationship developed between host and the pathogen. Thus, the pathogen continued to colonize the host tissues while symptoms began to appear as the pathogen continues to grow within the incubation period as 
shown by Maloy (1993), Richard (2003), Agrios (2005) on other pathogen-host interactions. Conidial germination brought considerable biochemical and physiological changes in plants due to the production of toxins and disruption of normal metabolic processes by the pathogen (Dickinson and Lucas, 1982; Agrios, 2005). The photosynthesis process can also be reduced dramatically if the pathogen grow into and disrupt or kill the hosts' tissues (Agrios, 2005). Therefore, as disease continues to develop, more tissues become chlorotic (yellowish due to lack of active chlorophyll) or necrotic (dead). Natural openings such as stomata and hydathodes on the leaves could facilitate spore germination and penetration host of the tissues (Dickinson and Lucas, 1982; Agrios, 2005).

Under pathogen stress, several yield components of sugarcane are significantly affected. As a result of infection the vegetative composition of the mature sugarcane plants was highly affected.

Pokkah boeng disease increased significantly number of tillers/plant of the tested sugarcane varieties. This might ascribe to the pathogen caused rot and knife cut of tops of sugarcane plants, therefore, plants trend to forming tillers more. In general, the number of tillers/plant was increased in susceptible varieties more than the resistant varieties, this might be attributed to geneticall differences between varieties.

A significant reduction was observed in number of internodes/plant of almost all tested sugarcane varieties after infection with both fungal pathogenic isolates. The highest number of internodes/plant was recorded in sugarcane plants noninoculated with the pathogen in the two tested seasons. These results are in agreement with those obtained by Atul Singh et al., (2006).

Stalk length of sugarcane plants significantly reduced by infection with fungal pathogen in the most of tested sugarcane varieties. The stalk length of sugarcane plants was higher in non-inoculated plants than in plants infected with $\mathrm{K} 2$ and $\mathrm{K} 5$ isolates of $F$. subglutinans in the first and second seasons, such results are in accordance with those reported by Singh and Goswami (2002) and Atul Singh et al., (2006). The stalk elongate rapidly producing a number of internodes which are more or less constant for each variety. The length of internodes is determined by climatic and field conditions as wall as variety. El-Debaby et al., (1996), Ahmed (1998) and Ahmed (2005) obtained the same results. The difference in stalk length among sugarcane varieties due to their differences in genetic potential controlling the stalk formation and elongation. Differences in stalk length among sugarcane varieties were reported by Abo El-Ghait (2000) and El-Shafai and Ismail (2006).

The infection of sugarcane plants with both tested isolates (K2 and $\mathrm{K} 5$ ) resulted a decrease in stalk cane diameter in tested sugarcane varieties. Stalk diameter of sugarcane markedly decreased in plants infected with both isolates. These findings are in agreement with those obtained by Singh and Goswami (2002) and Atul Singh et al., (2006). This difference between varieties in this character may be due to the differences in genetically aspects between varieties. Differences in stalk diameter among sugarcane varieties were previously reported by Mohamed and Ahmed (2005). 
References:

Abo El-Ghait, R. A. M. (2000). Estimation of stability parameters for some sugarcane varieties., Ph.D. Thesis, Fac. Agric. Minoufiya Univ., Egypt.

Agrios, G. N. (2005). Plant Pathology (5th ed). Harcourt Academic Press, New York. 687pp.

Ahmad, M. and Ali, R. (1991). Screening of genetic stock of sugarcane against pokkah boeng. Pakistan Journal of Phytopathology. 3(1-2): 26-28.

Ahmad, Z.; Khan, S.; Rahman, S.; Ahmad, G. and Khan, D. (1998). Yield and quality of sugarcane as affected by different levels of nitrogen and planting density. Pakistan-Sugar-Journal., 12:(2) 29-33.

Ahmed, Z. A. (2005). Response of some promising sugarcane varieties to different levels of nitrogen fertilizer. Afrecan Crop Science Conference Proceedings, (7): 155-160.

Atul Singh.; Chauhan, S. S; Aneg, S. and Singh, S. B. (2006). Deterioration in sugarcane due to pokkah boeng disease. Sugar Technology 8 (2/3): 187-190.

Blackburn, F. (1984). Sugarcane. London and New York: Longman, pp: 220-234.

Chattha, A. A.; Ali, F. G. and Afghan, S. (1999). An early maturing and high sugar variety CPF-236 developed by Sugarcane Research Institute, Faisalabad. Pakistan Sugar Journal, 14(6): 14-15.

Chattha, A. A.; Anwar, M. S. and Ali, F. G. (2002). Cane variety SPF234: a medium maturing variety for spring sowing in Southern region of the Punjab. Pakistan Sugar Journal, 17(6): 29-38.
Cuenya, M. I.; Chavanne, E. R.; Ostengo, S.; Garcia, M. B.; Ahmed, M.; Costilla, D. D.; Diaz Romero, C.; Espinosa, M. A.; Delgado, N. and Diaz, J. V. (2011). Productive and phytosanitary TUC 95-10, a new sugarcane cultivar produced by the EEAOC. Avance Agroindustrial, 32 (4): 14-21.

Dickinson, C. H. and Lucas, J. A. (1982). Plant pathology and plant pathogens (2nd ed.). Blackwell Scientific Publications. 229 pp.

El-Debaby, A. S.; El-Geddawi, I. H.; Saad, A. M. M. and Azzazy, N. B. (1996). Effect of some irrigation systems and nitrogen fertilizer on growth characters of some sugar cane varieties. Annals-of-Agricultural-Science,Moshtohor. 34 (3): 811-821.

El-Shafai, A. M. A and Ismail, A. M. A. (2006). Effect of row spacing on yield and quality of some promising sugarcane varieties. Egypt. J. of Appl. Sci., 21 (11).

Freed, R. S. P.; Eisensmith, S. P. Goetez, S.; Recosky, D.; Smail. V. W. and Wolberg, P. (1989). User's Guide MSTAT-C Asoftwere program for the design management and analysis of agronomic research experiments. Michingan State University, U.S.A.

Gomez, K. A. and Gomez, A. A. (1984). Statistical Procedures for Agricultural Research. A. Willey- Interscience Publication. New York 678 pp.

Higgy, A. H. (19`6). Studies on pokkah boeng disease of sugarcane. Phd. Sc. Thesis, faculty, Agric., Assiut Univ., Egypt, 140 pp.

Islam, M. S.; Miah, S. A. M.; Begum, K. M.; Alam, R. M. and Arefin 
S. M. (2001). Growth, Yield and Juice Quality of Some Selected Sugarcane Clones Under, WaterLogging Stress Condition. World Journal of Agricultural Sciences 7: 504-509.

Javed, M. A.; Chaudhry, B. A.; Tanvir, M. K.; Shahid, M. T. H. and Makhdoom, H. (2001). Development and screening of sugarcane somaclones against diseases. Pakistan Sugar Journal.16 (6): 36-39.

Lyrene, P. M.; Dean, J. L. and James, N. I. (1977). Inheritance of resistance of pokkah boeng in sugarcane crosses. Phytopathology. 67: 689-692.

Maloy, O. C. (1993). Plant disease control: principle and practice. John Wiley and Sons Inc. 346 pp.

Martin, J. P.; Abbot, E. V. and Hughes, C. G. (1961). Sugarcane diseases of the worled. Vol: (1) Elsevier Publishing Co. Amsterdam. $542 \mathrm{pp}$.

Mohamed, B. D. and Ahmed, Z. A. (2005). Response of three sugar cane varieties to varing nitrogen fertilizer rates. The 11th Conference of Agronomy, Agron. Dept., Fac. Agric., Assiut Univ., Nov. 15-16.

Patil, A. S.; Singh, H.; Sharma, S. R. and Rao, G. P. (2007). Morphology and pathogenecity of isolates of Fusarium moniliformae causing Pokkah boeng of sugarcane in Maharastra. Microbial Diversity: Modern Trends, Daya Publishers, New Delhi 234-263.

Priode, C. N. (1929). Pokkah bong and twisted top disease of sugar cane in Cuba. Phytopathology, 19 (4): 343-366.

Rahman, M. S.; Talukder, M. I.; Khatun, S.; Siddique, A. B. and Amanullah, A. S. M. (2009).
Evaluation of some promising sugarcane genotypes for resistance to wilt disease. International Journal of Sustainable Agricultural Technology, 5 (8): 710.

Ramirez, E. and Nass, H. (2005). Status pokkah boeng (Fusarium moniliforme) in Yaracuy Yaritagua in the years 2003 to 2005. VI Congreso Nacional Sugar atavistic. (Memoirs CD rom version).

Richard, N. S. (2003). Introduction to plant pathology. John Wiley and Sons Ltd. 464 pp.

Singh, S. N. and Goswami, G. P. (2002). Evaluation of sugarcane varieties for resistance to wilt disease caused by Fusarium moniliforme. Annals of Plant Protection Sciences, 10 (1): 163164.

Solanky, K. U.; Sabalpara, A. N. and Mehta, B. P. (2003). Evaluation of sugarcane clones/varieties for resistance to wilt. Indian Phytopathological Society, 56: (1) 123.

Urdaneta, J. and Borges, J. A. (2008). Behavior of five fungical pathologies in 14 sugar cane cultivars (Saccharum spp.) with forage aims in Yaracuy state, Venezuela. Revista de la Facultad de Agronomia, Universidad del Zulia. 25: (3) 455-469.

Vishwakarma, S. K.; Kumar, P.; Nigam, A.; Singh, A. and Kumar, A. (2013). Pokkah boeng: An emerging disease of sugarcane. Journal plant pathology and Microbiology, 4 (3): 170.

Yates, I. E.; Bacon, C. W. and Hinton, D. M. (1997). Effects of endophytic infection by Fusarium moniliforme on corn 
growth and cellular morphology.

Plant Disease, 81: 723-728. 
استجابه بعض اصناف قصب السكر للاصابه بمرض Pokkah boeng المتسبب عن الفطر .Fusarium subglutenans

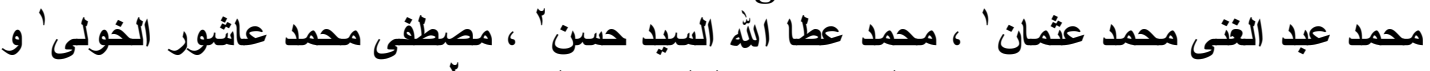

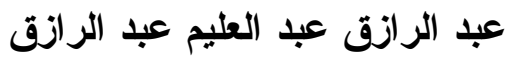

'معهد بحوث المحاصيل السكريه، قسم بحوث افات وامر اض المحاصيل المبل السكريه، مركز البحوث الزر اعيه،

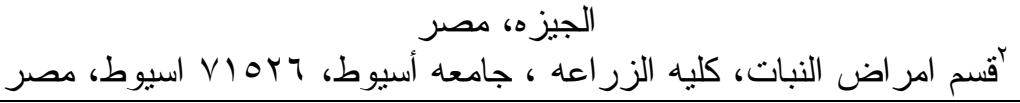

الملخص:

تم اختبار حساسيه سته عثر صنفا من اصناف قصب السكر للاصـابه بمـرض pokkah boeng وتم اختبار تاثير المرض على صفات النمو الخضريه فى النباتــات المــصـابه المعديــهـ صناعيا بعزلتين من المسبب المرضى (K2 و K5) للفطر Fusarium subglutenans وذلك

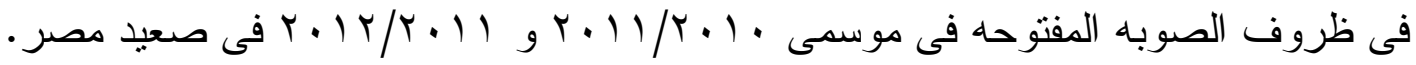
اظهرت كل اصناف قصب السكر المختبره حساسيتها للاصـابه بكلتا العزلتين من المـسبب المرضى مع وجود اختلافات فى درجات حساسيتها للاصابه. فى كلا من موسمي الاختبار وجد ان الصنفين G.T.54-9 و G.2004-32 اكثر حساسيه للاصابه لكل من العزلتين K2 و K5 وتلاهم الاصناف G.2003-47، G.2003-3 ، G.1999-103 و G.1998-28 وتلاهــــ بقيــه الاصناف المختبره.

حيث ان الاصناف G.2001-79 و G.2000-176 اظهرت حساسيه متوسطه للاصــابه. وبالنسبه للقدره المرضيه لعز لات الفطر المسبب للمرض، وجد ان العزله K2 سبيت اعلى شـــه مرضيه عن العزله K5، وذلك على اصناف قصب السكر المختبره فى كلا الموســمين. وجـــ تفاعل معنوى بين الاصناف المختبره وبين عز لات المسبب المرضى فى كلا الموسمين. وقـــ سجل الصنفين G.T.54-9 و G.2004-32 اعلى شده اصابه (72.0 و 76.0\%) وذلـــ عنـــ العدوى بالعزله K2 من الفطر Fusarium subglutenans فى كلا الموسمين، بينما اقل شده مرضيه (20\%) سجلت على الاصناف G.2001-79 و 176-2000 G. G و المعديه بـالعزلتين K2 و K5. ان العدوى بالعزلــه K2 او K5 مسـن الفطـر Fusarium subglutenans ادى لزياده عدد الخلفات/نبات وذلك فى النباتات المصابه بالمقارنه بالنباتـات الـسليمه فــى كـلا الموسمين، فى حين ان عدد العقل/نبات، طول الساق و سمك الساق فــى الاصـــناف المختبــره و المعديه قلت بدرجه معنويه نتيجه للاصنابه. 